\title{
MEDITERRANEAN OCTOCORALLIA: DESCRIPTION OF CLAVULARIA CARPEDIEM N. SP. AND SYNONYMY OF CLAVULARIA CRASSA AND C. OCHRACEA ON ETHO-ECOLOGICAL GROUNDS
}

\author{
by \\ STEVEN WEINBERG \\ Institute of Taxonomic Zoology, University of Amsterdam, The Netherlands ${ }^{1}$ )
}

\begin{abstract}
A new stoloniferan octocoral from the Mediterranean (Morocco) is described under the name Clavularia carpediem and critically compared with $C$. marioni Von Koch, 1891 and $C$. arctica (Sars, 1861). A thorough redescription of the latter species is given.

The recent discovery that the common rock-dwelling colonies belonging to a species hitherto referred to as $C$. ochracea Von Koch, 1878 incubate their eggs on the outside of the polyps, a rather unusual fact among Octocorallia, leads to the synonymy of this species with $C$. crassa (Milne Edwards, 1848), so far considered a rare species living exclusively as an epibiont on the Mediterranean sea-grass Posidonia oceanica.

\section{RÉSUMÉ}

Sous le nom Clavularia carpediem un nouvel Octocoralliaire Stolonifère méditerranéen est décrit des côtes marocaines, et une comparaison critique est donnée de la nouvelle espèce avec $C$. marioni Von Koch, 1891 et $C$. arctica (Sars, 1861). Cette dernière est redécrite en détail.

La découverte récente du fait que les Stoloniferes communs des substrats durs, connus jusqu'à présent sous le nom de $C$. ochracea Von Koch, 1878 incubent leurs oeufs à l'extérieur des polypes, un phénomène plutôt exceptionnel chez les Octocoralliaires, conduit à la synonymie de cette espèce avec $C$. crassa (Milne Edwards, 1848) que l'on considérait jusqu'à présent comme une espèce rare, vivant exclusivement en épibionte sur la Posidonie (Posidonia oceanica).
\end{abstract}

\section{INTRODUCTION}

The study of Octocorallia (Coelenterata, Anthozoa) originated in the Mediterranean Sea in pre-Linnaean times, and has been going on

1) Present address: European School, Boulevard Konrad Adenauer, L-1115 Luxembourg.

${ }^{2}$ ) Still described as Rolandia rosea (Philippi, 1842) in my paper on Mediterranean Stolonifera (Weinberg, 1978). since then. As a result, the Mediterranean octocoral fauna is quite well known, especially the circalittoral species that have recently been revised (Weinberg, 1976, 1977, 1978). Only three stoloniferan species have been described as being very common in the area: Cornularia cornucoprae (Pallas, 1766), Clavularia ochracea Von Koch, 1878 and Sarcodictyon roseum (Philippi, 1842) $)^{2}$.

Clavularia crassa (Milne Edwards, 1848), a species believed to live exclusively as an epibiont on the marine angiosperm Posidonia oceanica is much rarer, while the two remaining species appear to be very rare: Clavularia ("Anthelia") inermis, described by Bérenguier (1954), but of which the type-specimen has unfortunately been lost, may have been rediscovered near Benidorm, Spain (Williams, pers. comm.). The other species, Clavularia marioni, originally described from Naples by Von Koch (1891), and of which the typespecimen was lost as well, was subsequently found off Monaco, off Casablanca and around the Azores, in depths ranging from 845-2165 m (Thomson, 1927; Tixier-Durivault \& d'Hondt, 1975). In a recent redescription of the species (Weinberg, 1978) I studied a specimen from Naples (Zoölogisch Museum Amsterdam coll. no. Coel. 7831), presently the only known specimen from the type-locality.

In July and September 1982, while diving along the Mediterranean coast of Morocco near Cabo Negro, an area extremely rich in

Manuel (1981) brought the congenerity of Sarcodictyon Forbes, 1849 and Rolandia De Lacaze-Duthiers, 1900 to my attention, and correctly established the former name as the only one valid by priority. 
Octocorallia $^{3}$ ), I found a stoloniferan which reminded me of $C$. marioni by the size of its polyps. I collected some colonies. Closer study of these revealed that although resembling $C$. marioni, the specimens bear more resemblance to the boreal species $C$. arctica. The differences between the Moroccan species and $C$. arctica are such, however, that the former deserves a taxonomical status of its own. In this paper the new species Clavularia carpediem will be described and compared with $C$. marioni and $C$. arctica.

Furthermore, entirely new etho-ecological observations on the species formerly described as $C$. ochracea lead to the synonymy of this taxon with $C$. crassa.

\section{MATERIAL AND METHODS}

Living specimens were observed and photographed under water by means of SCUBA diving prior to collecting. The animals were kept overnight in a solution of $0.5 \%$ $\mathrm{MgSO}_{4}$ in seawater in order to achieve anesthesia before fixation in $10 \%$ formalin. Subsequently, the colonies were transferred to jars containing $70 \%$ ethanol. All specimens are kept in the collections of the Zoölogisch Museum of the University of Amsterdam (ZMA).

Specimens of Clavularia arctica were obtained from the Zoological Museum of the University of Bergen, Norway (ZMB: 457, 578, 579, 12162), the Zoological Museum of the University of Oslo, Norway (ZMO: B847, B1208) and the Zoological Museum of the University of Copenhagen, Denmark (collection numbers are dates of registration; ZMK: $20101884(3 \times), 05101889(2 \times), 15051890$, $04191896,26111908,22121953$, and two undated with the mention: "Tjalfe").

Preparations of sclerites were obtained by dissolution of the soft tissues in cold and concentrated sodium hypochlorite (Javel).

The morphological descriptions follow the nomenclature of Bayer et al. (1983).

\section{Clavularia carpediem n. sp.}

\section{Description}

Five colonies have been studied, the holotype (ZMA Coel. 8327) and four paratypes (ZMA

3) The following species were encountered: Clavularia crassa (Milne Edwards, 1848), Sarcodictyon roseum (Philippi, 1842), Maasella edwardsi (De Lacaze-Duthiers, 1888), Paralcyonium spinulosum (Delle Chiaje, 1822), Alcyonium acaule Marion, 1878, A. coralloides (Pallas, 1766) (see also
Coel. 8328, 8329, 8330). The colonies consist of groups of ca. 35-150 (mean 90) polyps rising at intervals of $1.4 \mathrm{~mm}$ (mean $2 \mathrm{~mm}$ ) from a stolonal network. The colonies appear as tight clusters of polyps (plate I, fig. A), even on substrata that would allow for much wider spacing of the individual polyps. The stolons are 2.5-20 mm wide, often consisting of a broad and flat membrane from which the polyps arise.

The polyps (fig. 1) consist of a 5.5-9 mm high anthostele which is completely stiffened by eight rows of densely packed sclerites. The proximal part of the anthocodia, which is completely retractile into the anthostele, bears only a few sclerites. On the distal part of the anthostele a crown and points occur, with about half a dozen intermediary sclerites between each pair of points. The crown consists of 5 to 9 parallel rows of long, slender sclerites, and the spindleshaped sclerites of the points are prolonged on the external side of the tentacles by sparsely distributed flat irregular tentacular sclerites (fig. 2).

These tentacular irregular plates (fig. 3) bear only a few tubercles.

Length: 49-167 $\mu \mathrm{m}$ (mean $107 \mu \mathrm{m})$.

Width: 16-45 $\mu \mathrm{m}$ (mean $30 \mu \mathrm{m}$ ).

Average length/width ratio: 3.6.

The sclerites of the crown and points (fig. 4) consist of very slender spindles with rounded thorns.

Length: $239-429 \mu \mathrm{m}$ (mean $295 \mu \mathrm{m}$ ).

Width: 26-37 $\mu \mathrm{m}$ (mean $31 \mu \mathrm{m}$ ).

Average length/width ratio: 9.5 .

The anthocodial sclerites (fig. 5) consist of relatively smooth spindles with rounded thorns. Length: $135-300 \mu \mathrm{m}$ (mean $208 \mu \mathrm{m}$ ).

Width: 26-41 $\mu$ m (mean $32 \mu \mathrm{m}$ ).

Average length/width ratio: 6.5 .

The sclerites of the anthostele (fig. 6) consist of two different forms: plump spindles densely

Groot Weinberg, 1982), Eunicella singularis (Esper, 1794), E. verrucosa (Pallas, 1766), Lophogorgia ceratophyta (Linnaeus, 1758), L. viminalis (Pallas, 1766) and Paramuricea clavata (Risso, 1826). 


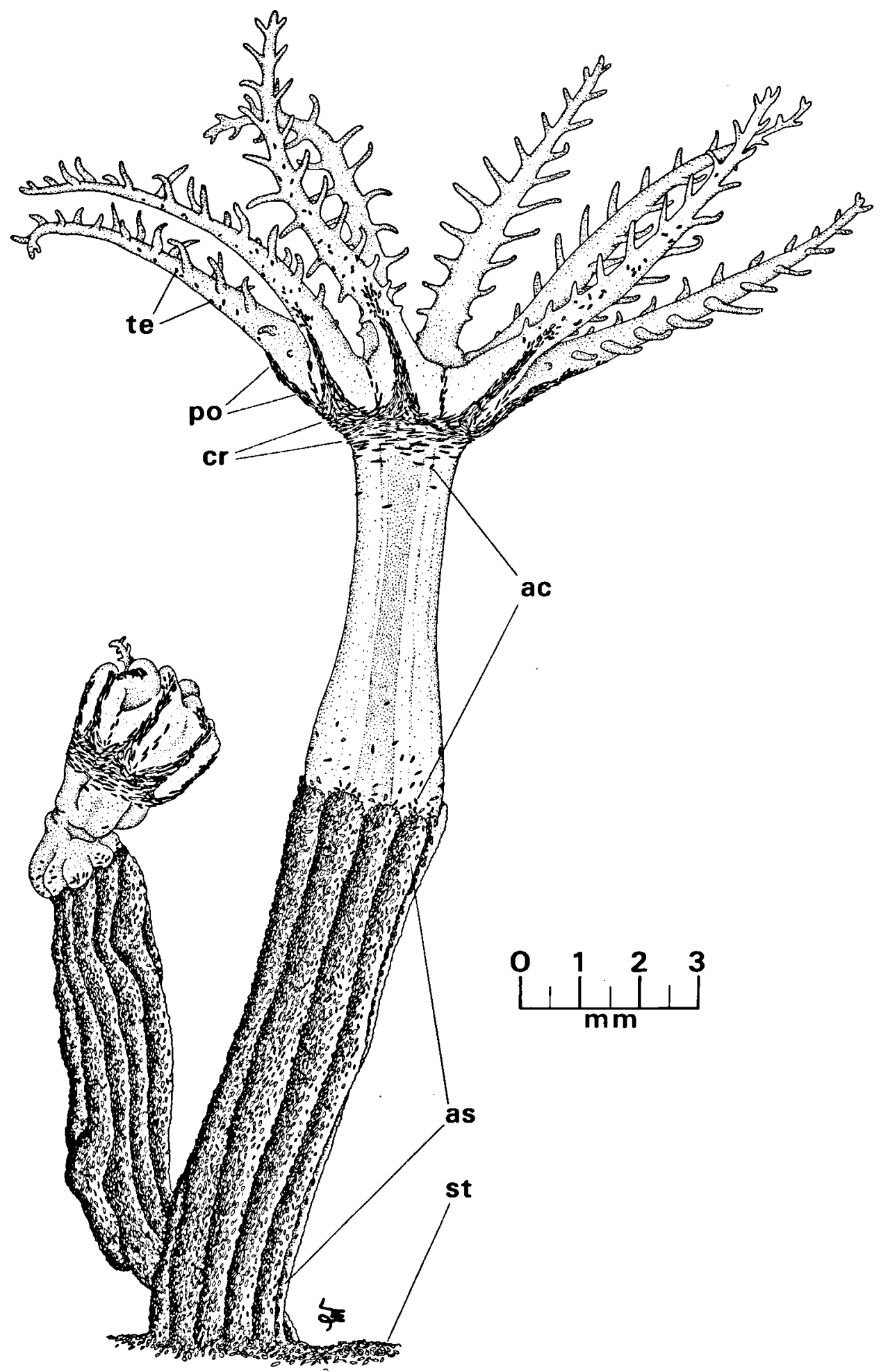

Fig. 1. Two polyps of Clavularia carpediem n. sp., one completely expanded, the other partly retracted. Sclerites occur in six distinct body regions: te $=$ tentacles, $\mathrm{po}=$ points, $\mathrm{cr}=\mathrm{crown}, \mathrm{ac}=$ anthocodia, $\mathrm{as}=$ anthostele, $\mathrm{st}=\mathrm{stolon}$. 


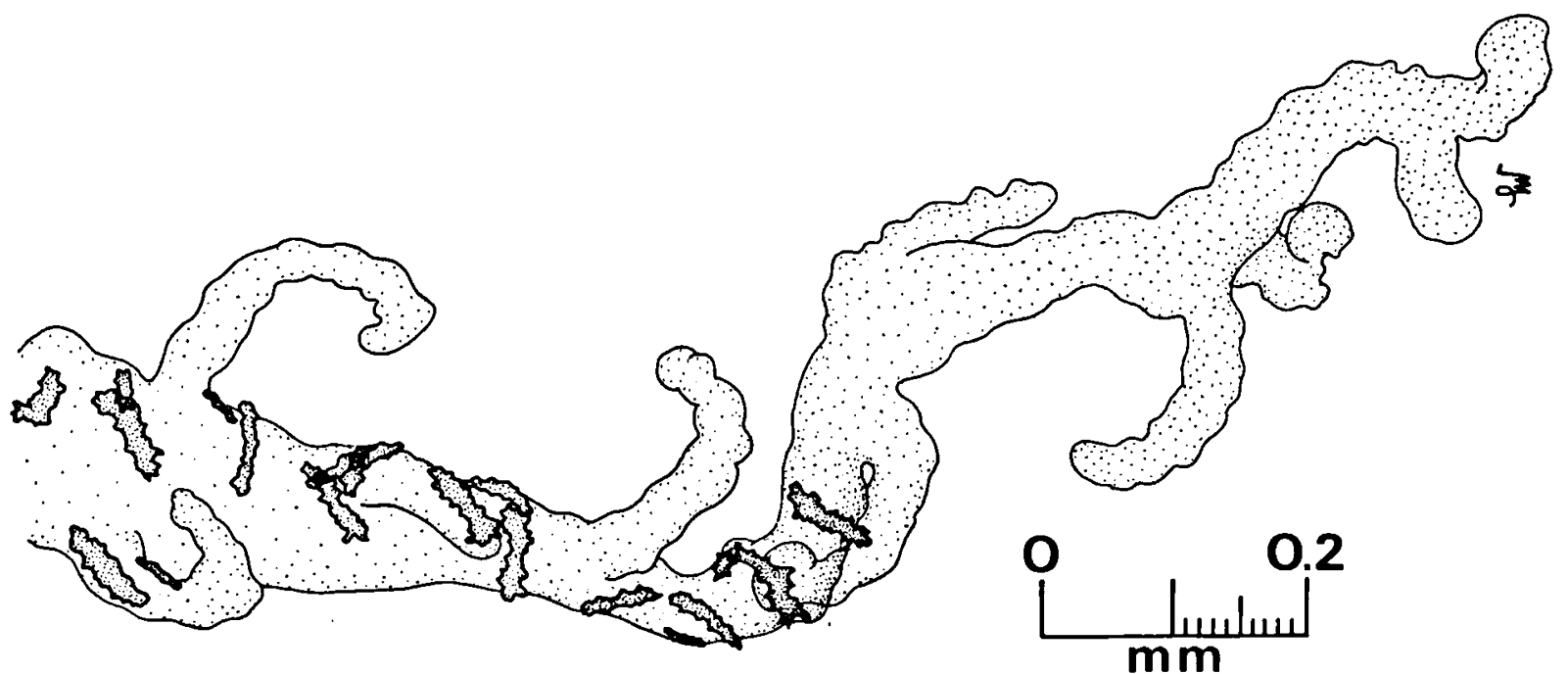

Fig. 2. Detail of a tentacle of Clavularia carpediem n. sp., with sclerites consisting of irregular flat plates.

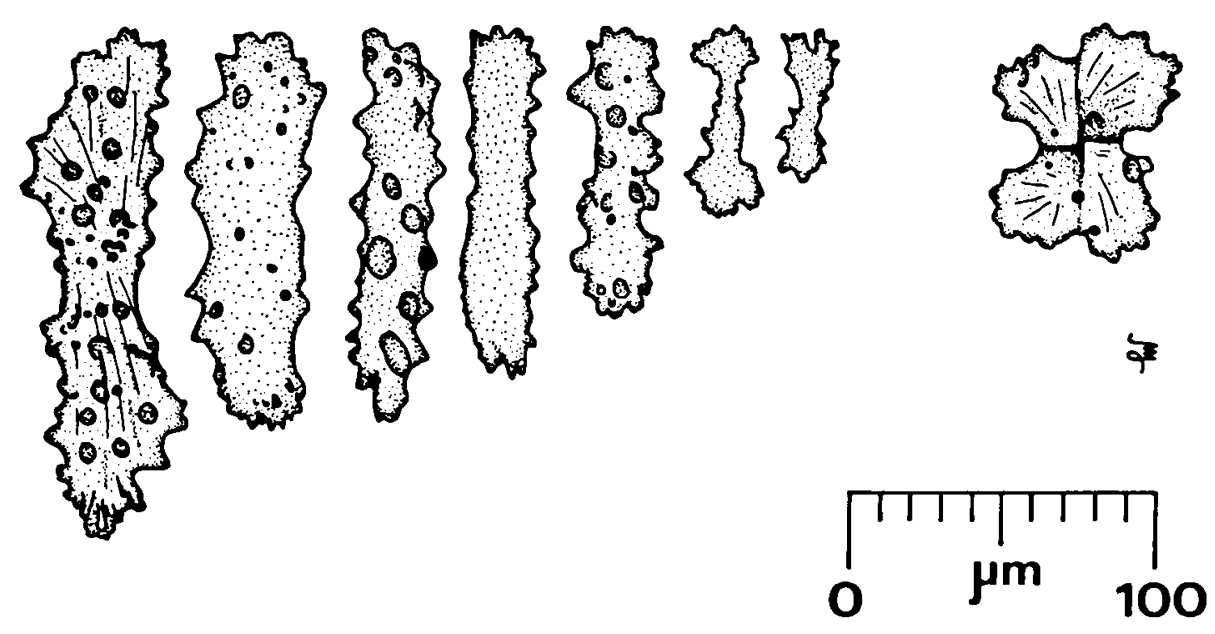

Fig. 3. Tentacular sclerites of Clavularia carpediem n. sp., consisting of irregular plates.

covered with tubercles, and slender spindles with rounded thorns.

Plump spindles:

Length: $149-378 \mu \mathrm{m}$ (mean $286 \mu \mathrm{m}$ ).

Width: 53-71 $\mu \mathrm{m}$ (mean $61 \mu \mathrm{m}$ ).

Average length/width ratio: 4.7 .

Slender spindles:

Length: 94-294 $\mu \mathrm{m}$ (mean $169 \mu \mathrm{m})$.

Width: 24-37 $\mu$ m (mean $31 \mu \mathrm{m}$ ).

Average length/width ratio: 5.5 .
The stolonal sclerites (fig. 7) consist of the same categories as encountered in the anthostele, although the surface processes of the slender spindles are more pronounced and sometimes more truncated and wart-like.

Plump spindles:

Length: $212-290 \mu \mathrm{m}$.

Width: 51-55 $\mu \mathrm{m}$.

Average length/width ratio: 5.4 . 


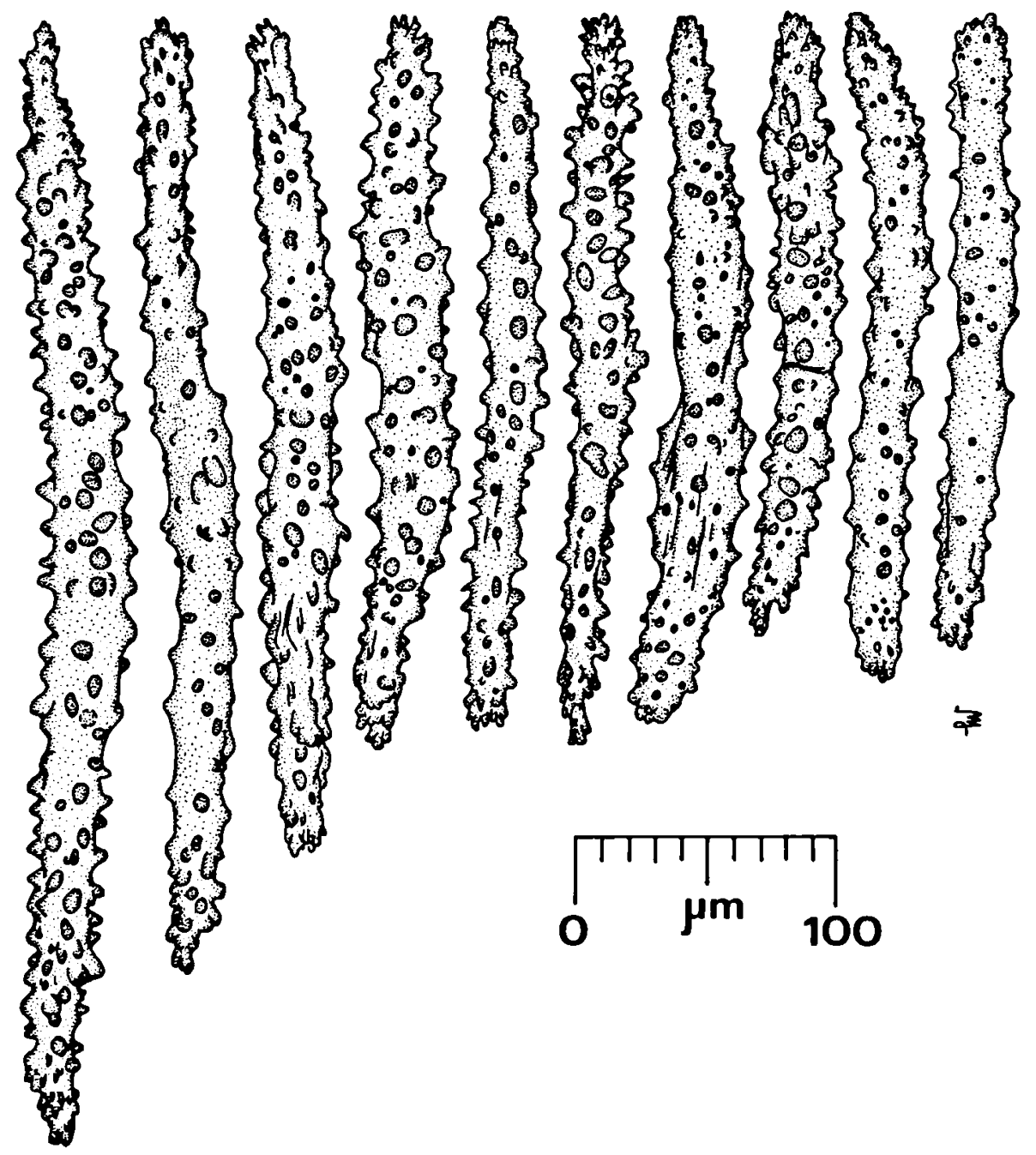

Fig. 4. Sclerites of crown and points of Clavularia carpediem n. sp.: slender spindles with rounded thorns.

Slender spindles:

Length: 90-261 $\mu \mathrm{m}$ (mean $192 \mu \mathrm{m}$ ).

Width: $26-45 \mu$ m (mean $34 \mu \mathrm{m}$ ).

Average length/width ratio: 5.7.

Cross-shaped sclerites occur in limited numbers throughout the colony.

\section{Distribution and ecology}

The species has been encountered so far in shallow water (15-22 m depth) north of Cabo Negro, near M'diq, Morocco. The colonies grow on the upper side of rocks covered by encrusting calcareous algae or on the bare stumps of gorgonian axes. Although the waters around Cabo Negro carry a fair amount of sediment, the species clearly seems to avoid substrata where silt accumulates. It should be noted that typical colonies of $C$. ochracea $(=C$. crassa, see next section) were found in the same habitats.

So far, in spite of intensive prospecting, the new species was not encountered in either shallower or deeper habitats near the typelocality.

\section{Etymology}

The specific name carpediem should be treated as an "arbitrary combination of letters" in 


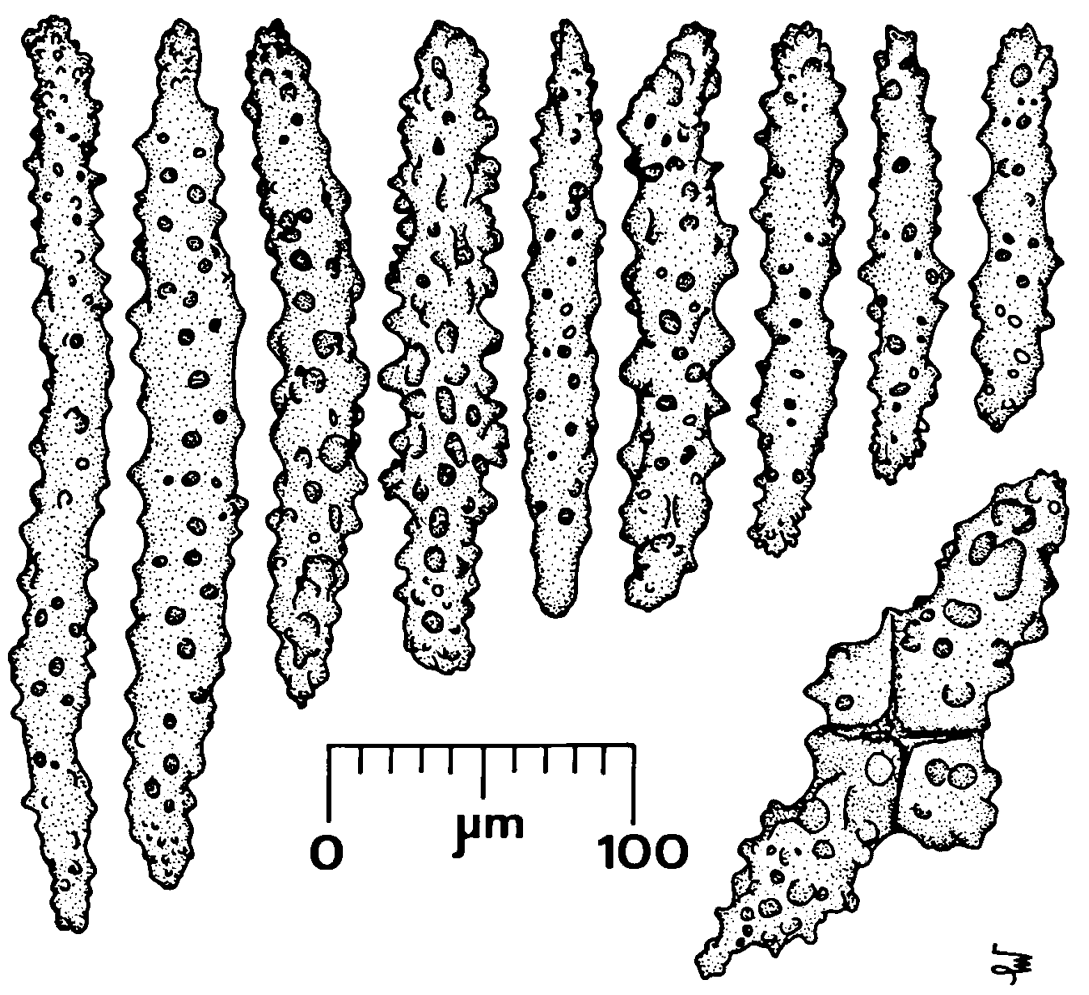

Fig. 5. Anthocodial sclerites of Clavularia carpediem n. sp.: spindles with rounded thorns.

accordance with article 11.b.iii of the International Code of Zoological Nomenclature (3rd ed., 1985). Classicists, however, will recognize here a contraction of "Carpe diem", a Latin proverb meaning "pluck the day" (i.e. "enjoy life"), referring to the holiday during which the author discovered the new species.

COMPARISON OF CLAVULARIA CARPEDIEM WITH C. MARIONI VON KOCH, 1891 AND C. ARCTICA (SARS, 1861)

Because of the close resemblance of Clavularia carpediem with $C$. marioni and $C$. arctica, a thorough comparison of the main characteristics of the three species was carried out. The results are summarized in table I.

\section{C. marioni}

This species was described in detail by Von Koch (1891) and Weinberg (1978), while the original descriptions of $C$. arctica by Sars (1861) and Koren \& Danielssen (1883) were completely revised by Broch (1912).

In the specimen of $C$. marioni from Bocca Piccola, Naples, $70 \mathrm{~m}$ depth, the type-locality (ZMA Coel. 7831), the distance between the up to $14 \mathrm{~mm}$ tall polyps is $3-8 \mathrm{~mm}$. The polypean sclerites are 40-210 $\mu \mathrm{m}$ long (mean $124 \mu \mathrm{m}$ ) and the stolonal sclerites measure 240-350 $\mu \mathrm{m}$ (mean $295 \mu \mathrm{m}$ ). Both are rather smooth spindles with low thorns. For a more detailed description of this sample, see Weinberg (1978).

In the original description (Von Koch, 1891: fig. 11 and pl. XXV figs. 6-9) the length of the polypean sclerites is some $40-240 \mu \mathrm{m}$ (average approximately $150 \mu \mathrm{m}$ ), while those of the stolon measure 100-300 $\mu \mathrm{m}$ (average approximately $280 \mu \mathrm{m}$ ).

\section{Conclusion}

C. marioni has somewhat smaller and plumper polyps with shorter tentacles than $C$. carpediem 


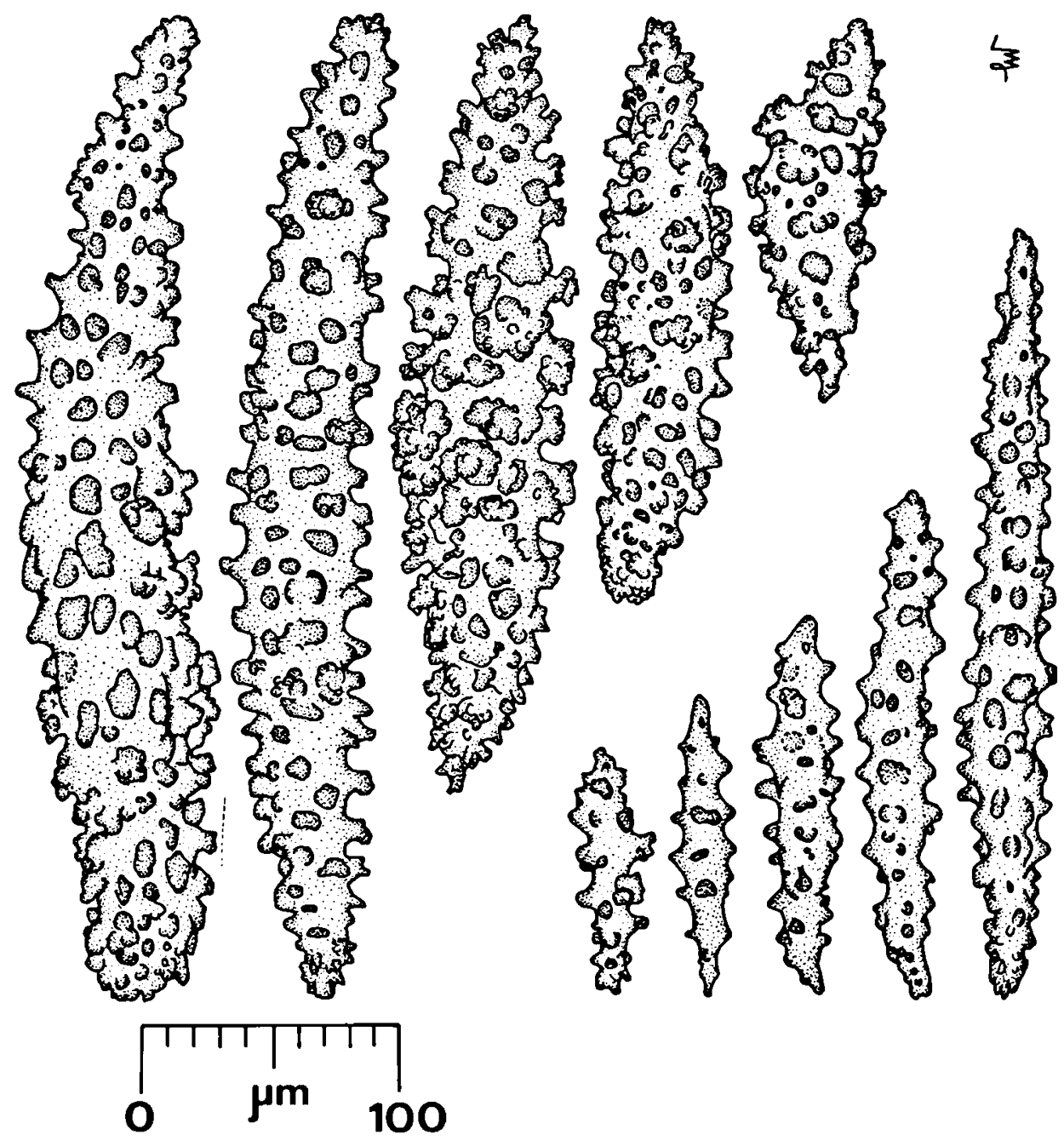

Fig. 6. Sclerites of anthostele of Clavularia carpediem n. sp. Top row: plump spindles densely covered with tubercles. Bot tom row: slender spindles with rounded thorns.

(but only preserved specimens of the former species have been observed!) and the polyps are more spaced from each other than is the case in $C$. carpediem. The crown and points of $C$. marioni contain less sclerites than $C$. carpediem. Its polypean sclerites are smaller, while stolonal sclerites are longer. The plump spindles with coarse tubercles that occur in anthostele and stolon of $C$. carpediem are absent in $C$. marioni. Although $C$. carpediem occurs within the known distributional range of $C$. marioni (Mediterranean, Casablanca, Azores), there is no overlap in depth range, $C$. carpediem being a shallow- water species, while $C$. marioni is restricted to deeper water.

\section{C. arctica}

Specimens of this species were obtained from the Zoological Museums in Copenhagen (Denmark), in Oslo (Norway) and in Bergen (Norway), including the specimens nrs. ZMB 578 and ZMB 579 collected by Koren \& Danielssen, being the syntypes of their $C$. arctica, which were studied by Broch, who added the following note (in Norvegian): "the type of Kor. \& Dan.'s 



Fig. 7. Sclerites of stolon of Clavularia carpediem n. sp.: plump spindles densely covered with tubercles and slender spindles with rounded thorns.

\section{TABLE I}

Comparison of the main characteristics of $\mathrm{Cc}=$ Clavularia carpediem n. sp., $\mathrm{Cm}=C$. marioni Von Koch, 1891 and $\mathrm{Ca}=C$. arctica (Sars, 1861). Data from Von Koch (1891), Broch (1912), Weinberg (1978) and new observations; * = important differences between $\mathrm{Cc}$ and the other species.

\begin{tabular}{lccc}
\hline & Cc & Cm & Ca \\
\hline height anthostele (mm) & $7.5-9$ & 7.5 & $9-16$ \\
maximum height polyp (mm) & 16 & 14 & 22 \\
maximum width polyp (mm) & 2.5 & 3.0 & 3.0 \\
max. length tentacles (mm) & 7.5 & 5.5 & 4.0 \\
number of pinnulae & $8-13$ & $8-10$ & $10-11$ \\
distance between polyps & & & \\
$\quad(m m)^{*}$ & $1-4$ & $3-8$ & $3-8$ \\
sclerites anthostele: & & & \\
maximum length $(\mu \mathrm{m}) *$ & 380 & 240 & 720 \\
average length $(\mu \mathrm{m})^{*}$ & 170 & 125 & 425 \\
average shape $(\mathrm{L} / \mathrm{W})^{*}$ & 5.1 & 4.9 & 4.4 \\
sclerites stolon: & & & \\
maximum length $(\mu \mathrm{m})^{*}$ & 290 & 350 & 510 \\
average length $(\mu \mathrm{m})^{*}$ & 190 & 295 & 290 \\
average shape $(\mathrm{L} / \mathrm{W})^{*}$ & 5.5 & 6.8 & 4.5 \\
depth range observed $(\mathrm{m})^{*}$ & $15-20$ & $70-2165$ & $35-300$ \\
\hline
\end{tabular}

Cl. arctica, described as $\mathrm{n}$. $\mathrm{sp}$. The species is, however, previously described by M. Sars as: Rhizoxenia arctica"'.

Another specimen, ZMB 457, identified by Sars, carries a label reading (in Norvegian): "Loc. Vardö is possibly a writing error for Vadsö". Since the descriptions by Koren \& Danielssen (1883) and Broch (1912) contain only few numerical data on the sclerites, I add a new description of the syntype (ZMB 578):

Locality: Vadsö, 50-60 fathoms (90-110 m).

Description: the sample consists of a piece of stone, on which a $2 \mathrm{~mm}$ wide stolon is found with about 6 polyps still attached to it, and about 20 detached polyps with a maximum width of $2.5 \mathrm{~mm}$ and a maximum height of 11.5 mm (Koren \& Danielssen, 1883, also mention 10-12 mm, but Broch, 1912, has described polyps up to $22 \mathrm{~mm}$ ).

Some sclerites are brown, filled with a fibrous, organic matrix.

Tentacular sclerites (fig. 8): flat, irregular plates; length: 103-243 $\mu \mathrm{m}$ (mean $165 \mu \mathrm{m}$ ), 


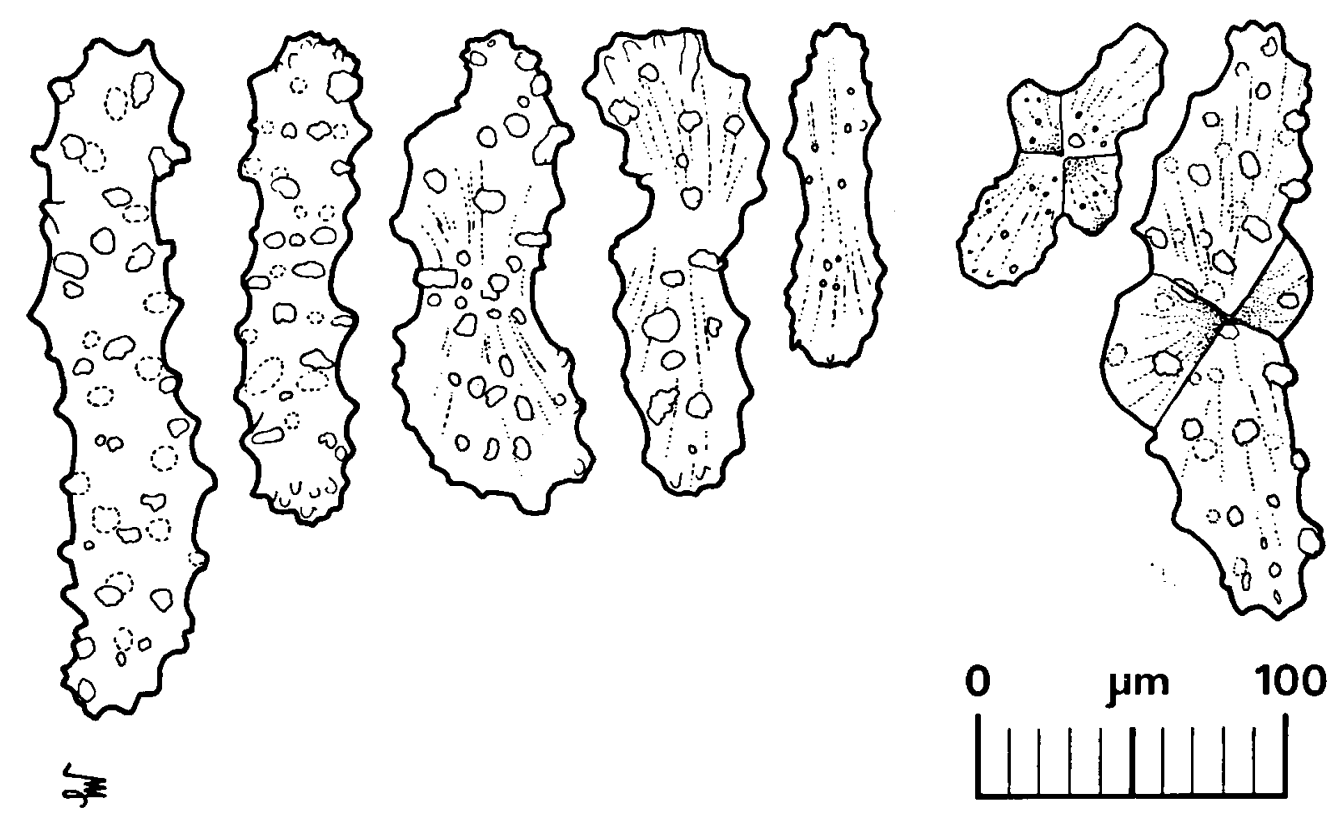

Fig. 8. Sclerites of tentacles of Clavularia arctica (ZMB 578), consisting of irregular plates.

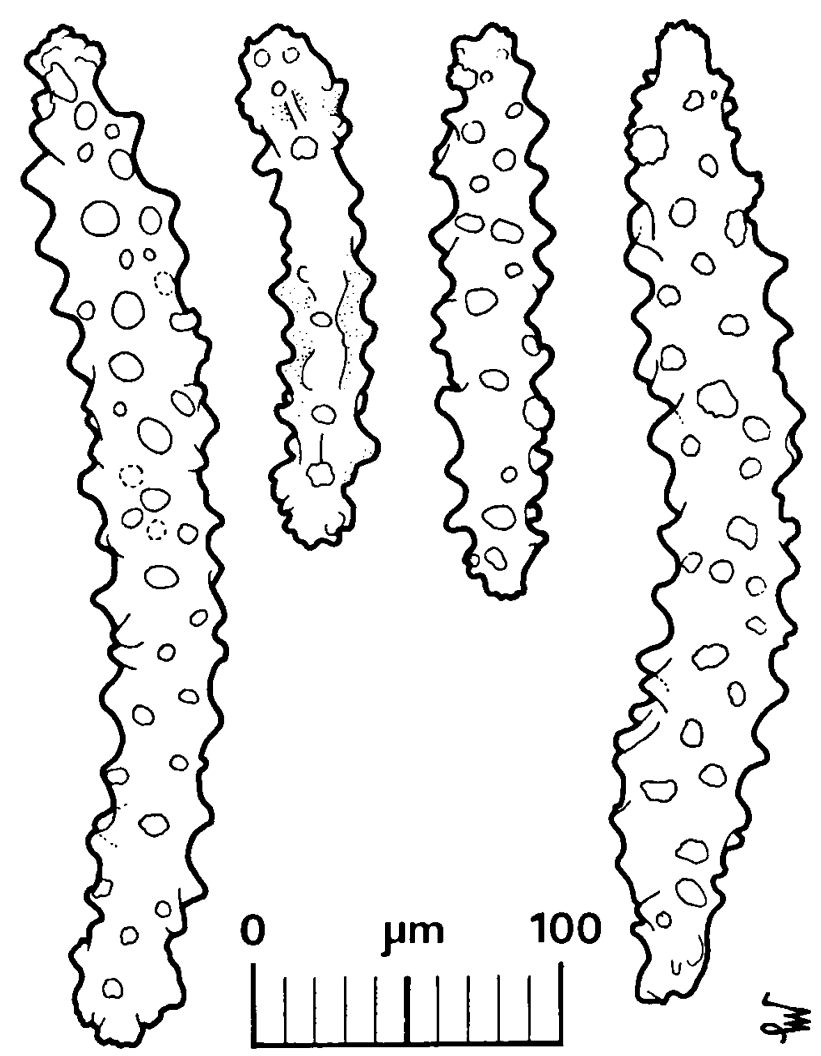

Fig. 9. Sclerites of anthocodia of Clavularia arctica (ZMB 578): spindles with rounded thorns and some warts. 
width: 29-60 $\mu \mathrm{m}$ (mean $45 \mu \mathrm{m}$ ), average length/width ratio: 3.6 .

Crown and points (fig. 10): slender spindles with small, rounded thorns; length: 194-480 $\mu \mathrm{m}$ (mean $351 \mu \mathrm{m}$ ), width: $33-70 \mu \mathrm{m}$ (mean 48 $\mu \mathrm{m})$, average length/width ratio: 7.4 .

Anthocodia (fig. 9): spindles with rounded thorns and some tubercles; length: $175-330 \mu \mathrm{m}$ (mean $237 \mu \mathrm{m}$ ), width: 25-58 $\mu \mathrm{m}$ (mean 42 $\mu \mathrm{m})$, average length/width ratio: 5.7 .
Anthostele (fig. 11): large, mostly plump, tuberculate spindles; length: $140-660 \mu \mathrm{m}$ (mean $423 \mu \mathrm{m}$ ), width: $33-140 \mu \mathrm{m}$ (mean $97 \mu \mathrm{m}$ ), average length/width ratio: 4.4 .

Stolon (fig. 12): rather smooth spindles, many small ones, some plump spindles with tubercles, length: 78-410 $\mu \mathrm{m}$ (mean $292 \mu \mathrm{m}$ ), width: 29-95 $\mu \mathrm{m}$ (mean $64 \mu \mathrm{m}$ ), average length/width ratio: 4.5 . Broch (1912) mentions stolonal sclerites of up to $510 \mu \mathrm{m}$.

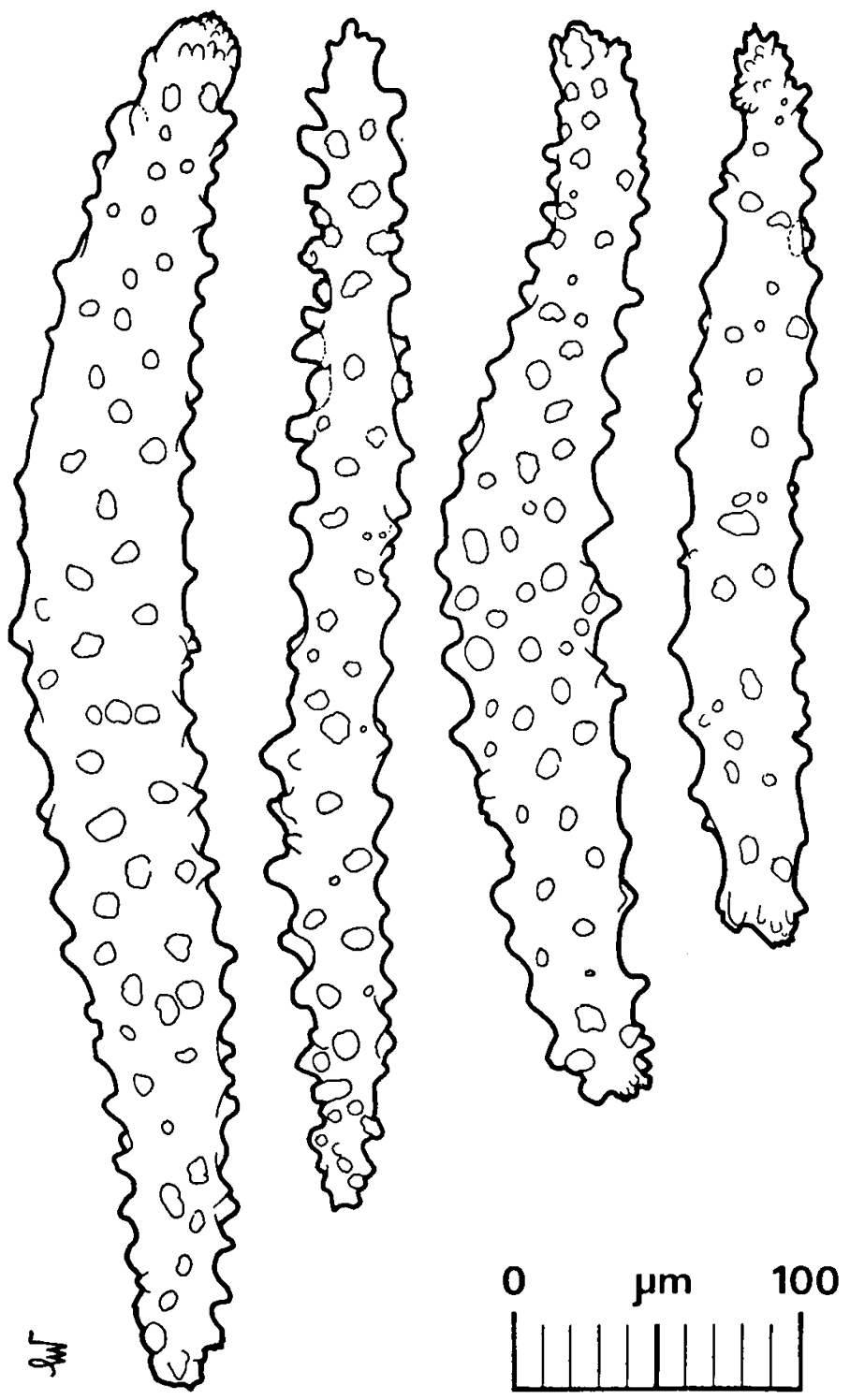

Fig. 10. Sclerites of crown and points of Clavularia arctica (ZMB 578): slender spindles with small, rounded thorns. 


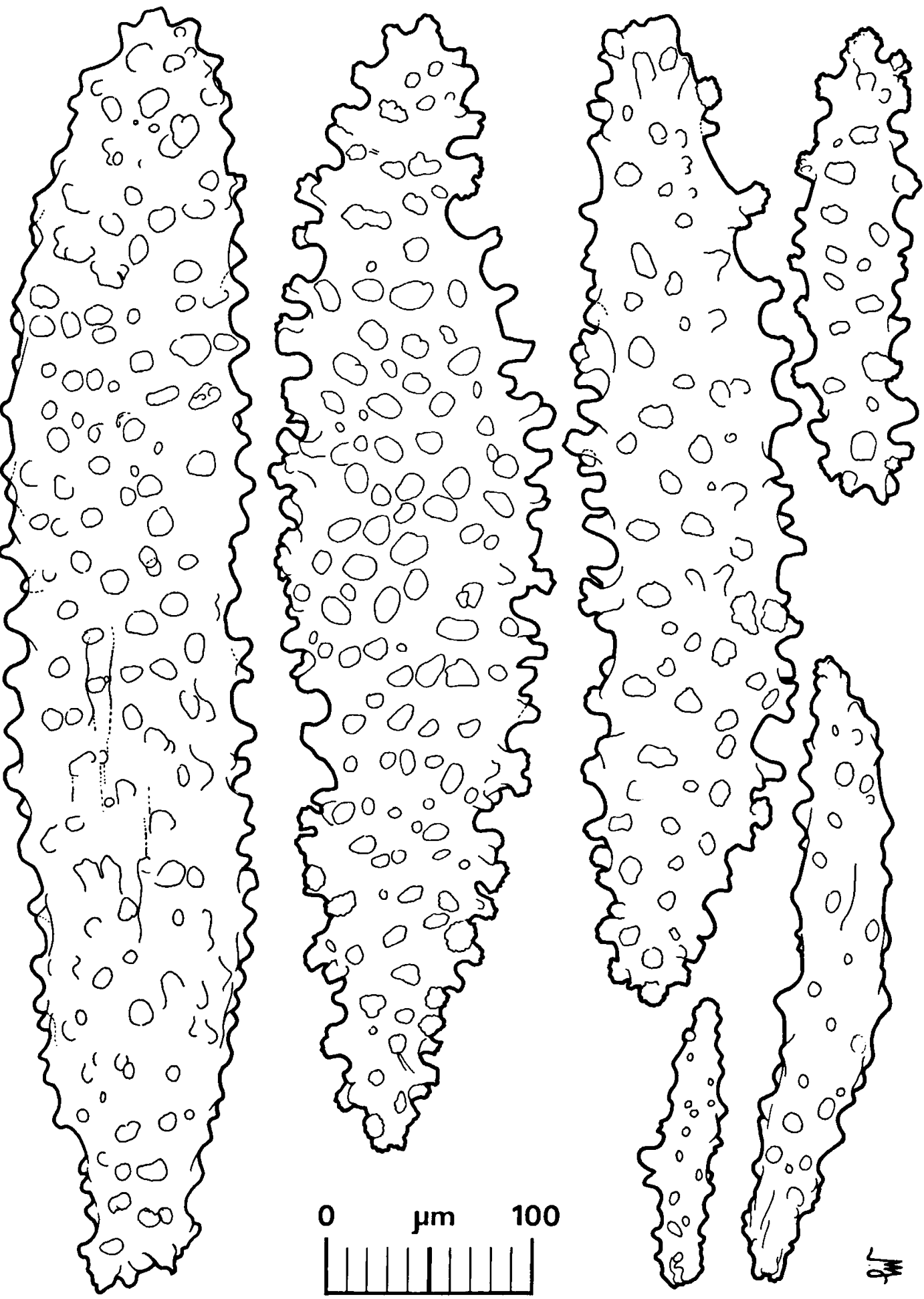

Fig. 11. Sclerites of anthostele of Clavularia arctica (ZMB 578): plump, tuberculate spindles. 


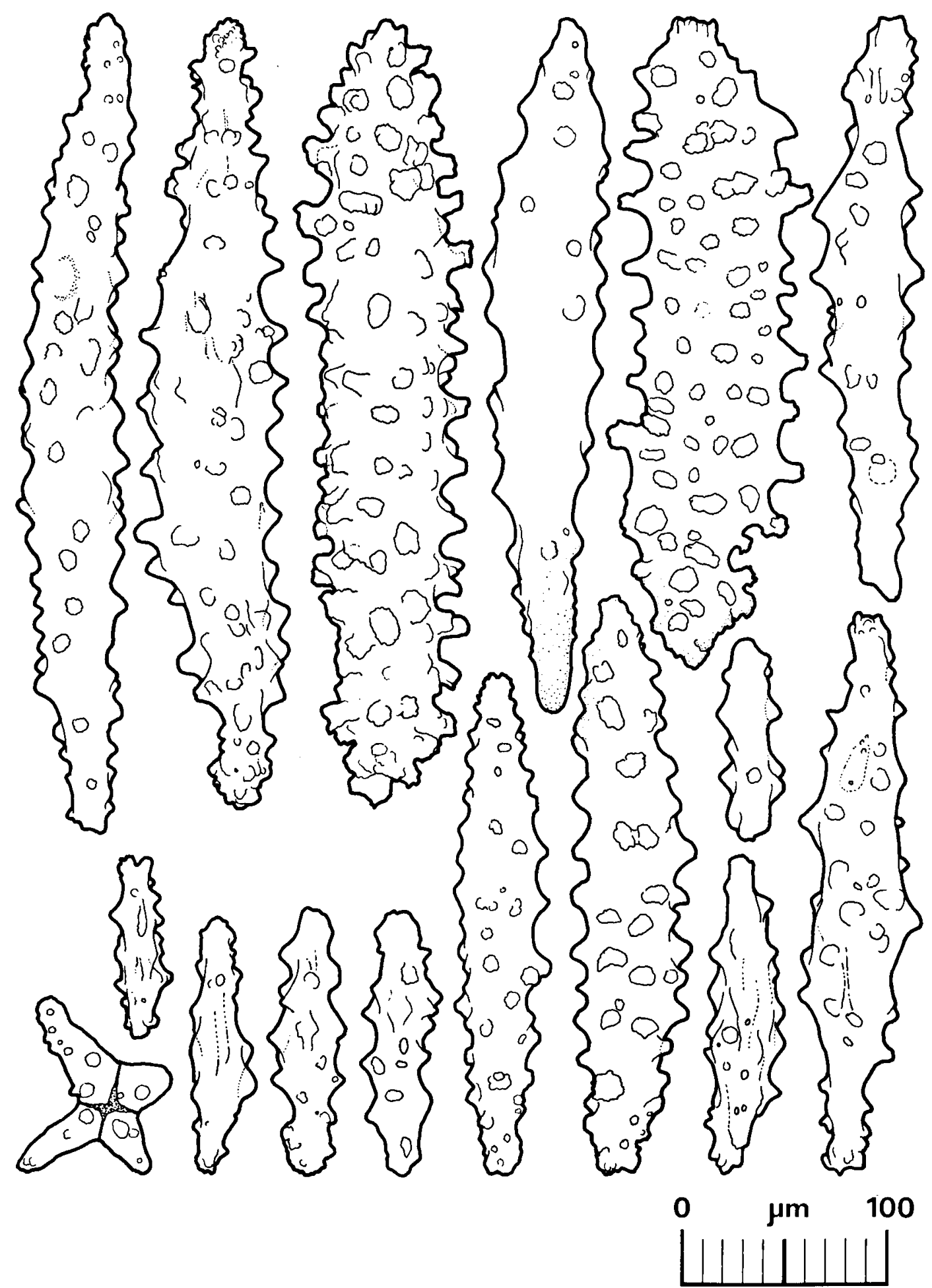

Fig. 12. Sclerites of stolon of Clavularia arctica (ZMB 578): many small, thorned spindles, some larger, tuberculate ones. 


\section{Conclusion}

In $C$. arctica the polyps are larger than in $C$. carpediem, while the tentacles are shorter (preserved specimens!). The polypean as well as the stolonal sclerites are much larger than the corresponding ones in $C$. carpediem, and the shapes of the sclerites are definitely different from those of $C$. carpediem. C. arctica occurs deeper than $C$. carpediem, and mostly in boreal waters (Madsen, 1944), although Thomson (1927) mentions the species from deeper water around the Azores. No distributional overlap occurs. Neither of the species have been encountered so far around the British Isles or along the Atlantic coasts of France, Spain and Portugal.

SYNONYMY OF CLAVULARIA OCHRACEA VON KOCH, 1878 AND C. CRASSA (MILNE EDWARDS, 1848)

In my revision of the Mediterranean Stolonifera (Weinberg, 1978), I paid particular attention to the genus Clavularia. At that time there was still a lot of confusion, and six species names existed: marioni Von Koch, 1891, crassa (Milne Edwards, 1848), ochracea Von Koch, 1878, petricola Kowalevsky \& Marion, 1883, inordinata Tixier-Durivault \& Lafargue, 1969 and steveninoae d'Hondt \& Tixier-Durivault, 1975.

I was able to show that several of these were synonyms, and I maintained three species only. Besides Clavularia marioni from deeper water, I described $C$. crassa as the species living on the rhizomes of the marine angiosperm Posidonia oceanica and incubating its eggs at the outside of the polyps, under the tentacles, and Clavularia ochracea as the species living on (see Weinberg, 1979): rock, the tunicate Microcosmus spp., and even on the crustacean Pisa nodipes, incubating its eggs internally, in normal octocoral fashion, on the mesenteries and expulsing freeswimming planula larvae.

However, I concluded (Weinberg, 1978: 160): "I wish to stress the fact that the separation of the species $C$. crassa and $C$. ochracea, their morphology being very similar, is based mainly upon Kowalewsky \& Marion's (1883) observa- tions on their different modes of reproduction. The rather peculiar way in which $C$. crassa incubates its eggs has recently been observed by d'Hondt \& Tixier-Durivault (1975). However, reconfirmation of planulae emission by $C$. ochracea is needed to establish the validity of two distinct species with certainty."

During the month of August 1984 I made some underwater observations in several stations near Banyuls-sur-Mer (France), that might well be conclusive to solve this taxonomical riddle. On vertical rock surfaces between 5 and $10 \mathrm{~m}$ depth there exist large populations of what I regarded so far, because of the habitat, as belonging to Clavularia ochracea. On the 4th of August 1984, I observed for the first time a colony incubating its orange eggs under the tentacles, on the outside of the polyps (see plate I: fig. C, and compare with Kowalevsky \& Marion, 1883, plate I, figs. 1 and $1 \mathrm{a}$ and d'Hondt \& Tixier-Durivault, 1975, fig. 4). In the following days the same phenomenon was observed on dozens of colonies, in depths ranging from 5 to $10 \mathrm{~m}$, and on the 9th of August the first planulae detached themselves from the mother polyps. The same phenomenon was observed again between July 16th and August 5 th, 1986.

So it has been clearly established now that the common rock-dwelling Mediterranean colonies of Clavularia can behave in the same way as was already known from the colonies living on seagrass. It still seems possible, however, that Kowalevsky \& Marion's (1883) observations were correct, and that, perhaps depending on environmental conditions, these clavularians can switch from one way of incubating their eggs to another.

Since the important ethological criterion of internal vs. external embryological development has thus disappeared, there seems to be no more valid reason to separate Clavularia into a rock-dwelling species and one that lives on sea-grass. I therefore conclude to the synonymy of the two species, where according to the priority rule Clavularia crassa (Milne Edwards, 1848) should be used henceforth. 


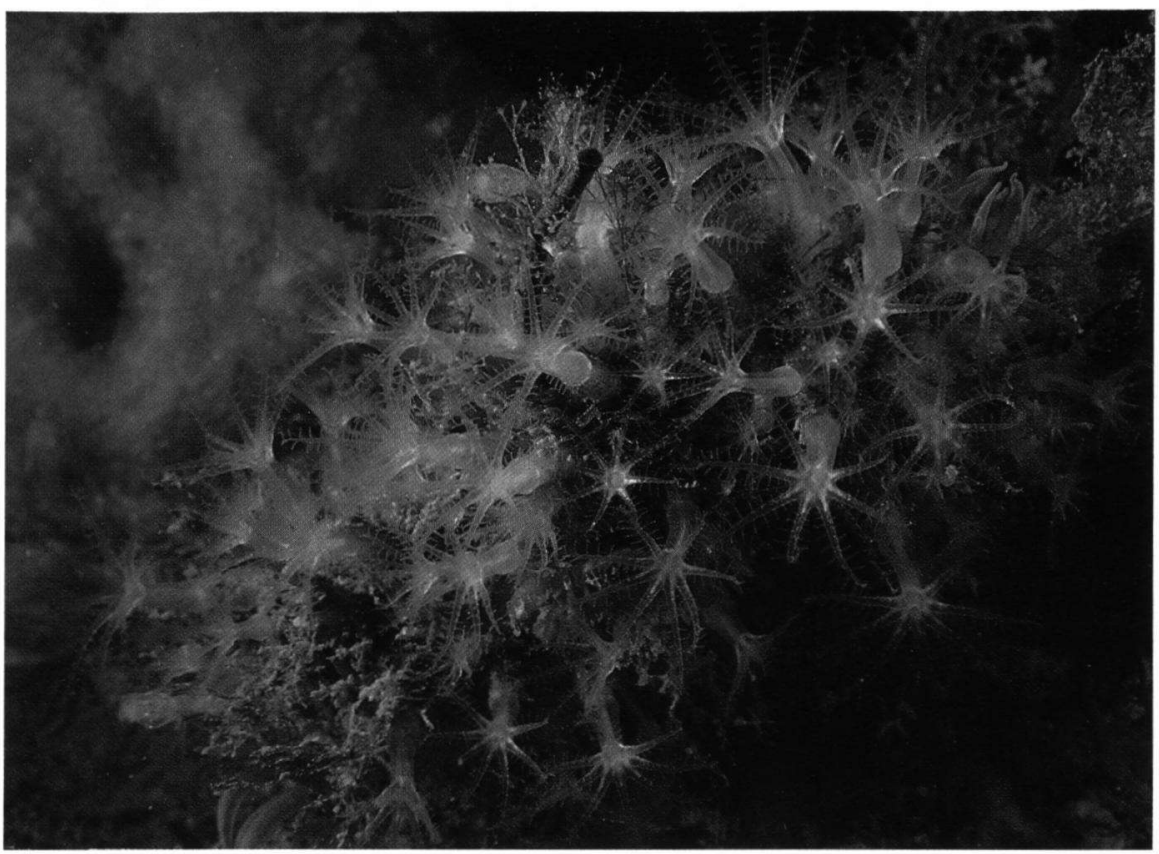

Plate I

Fig. A (top): Holotype of Clavularia carpediem n. sp. (ZMA Coel. 8327), photographed in situ at $22 \mathrm{~m}$ depth north of Cabo Negro, Morocco. Note that the polyps are densely grouped, a typical feature of the species $(1.7 \times)$.

Fig. B (left): Expanded polyps of Clavularia crassa growing on a rock surface amidst sponges, Banyulssur-Mer, ca. $10 \mathrm{~m}$ depth. Fig. C (right): Colony of Clavularia crassa in the same habitat as above. The orange eggs are being incubated in a mucous sheath at the outside of the polyps, under the tentacles. (All underwater pictures by the author.)
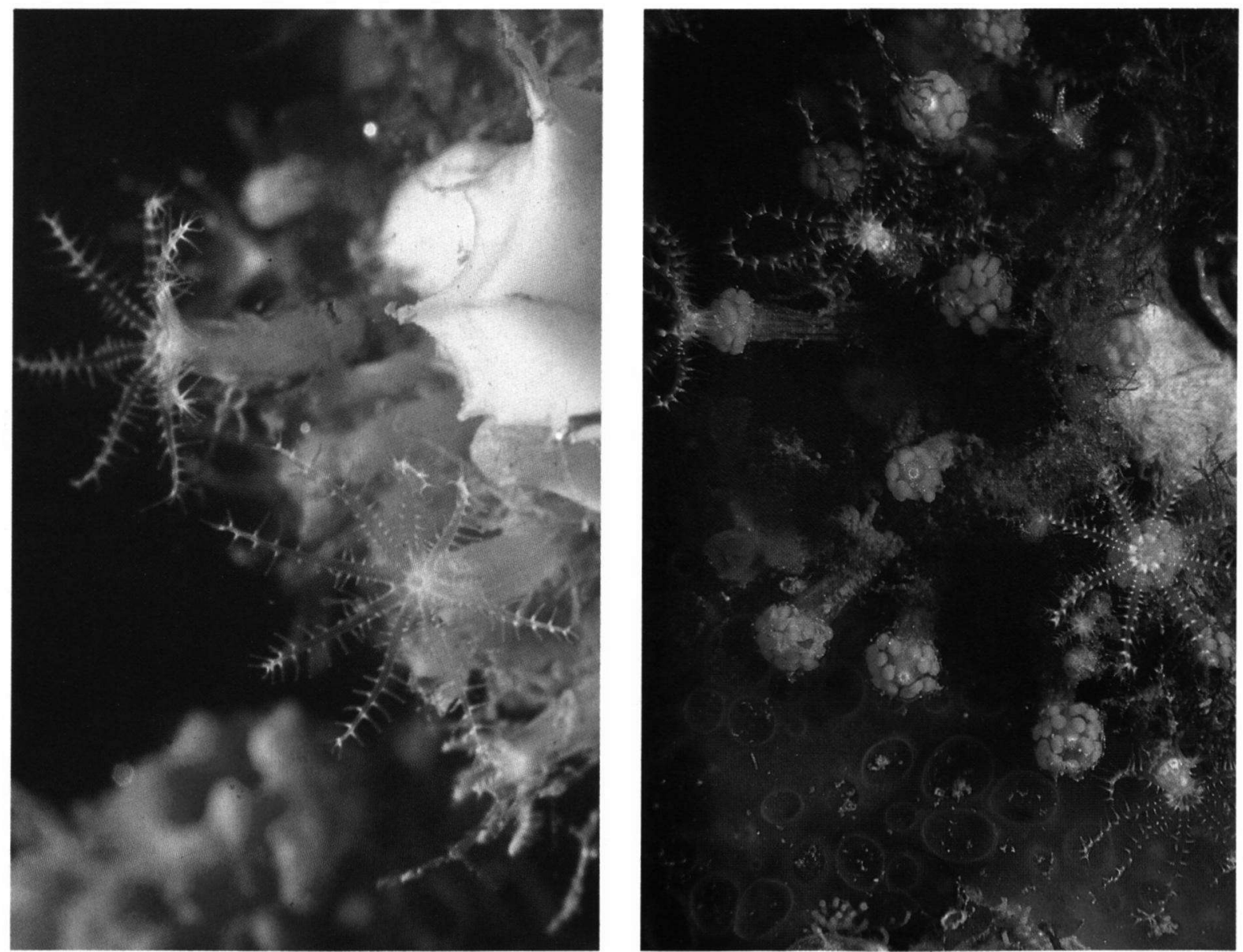


\section{ACKNOWLEDGEMENTS}

The following persons are acknowledged for loan of material: Dr. Endre Willassen (Zoological Museum, University of Bergen, Norway), Dr. Marit Christiansen (Zoological Museum of the University of Oslo, Norway), Dr. Kay Petersen (Zoological Museum, University of Copenhagen, Denmark) and Dr. Rob van Soest (Institute of Taxonomic Zoology, University of Amsterdam, The Netherlands). The magazine "Vita Marina" kindly contributed the separation negatives for plate I.

\section{REFERENCES}

Bayer, F. M., M. Grasshoff \& J. Verseveldt (eds.), 1983. Illustrated trilingual glossary of morphological and anatomical terms applied to Octocorallia: 1-75, pls. 1-20 (E. J. Brill, Leiden).

Bérenguier, A., 1954. Contribution à l'étude des Octocoralliaires de Méditerranée occidentale. Recl. Trav. Stn. mar. Endoume, 12 (7): 53-96.

Broch, H., 1912. Bemerkungen über Clavularia arctica (M. Sars). K. norske Vidensk. Selsk. Skr., 1911 (4): 1-8.

Groot, S. \& S. Weinberc, 1982. Biogeography, taxonomical status and ecology of Alcyonium (Parerythropodium) coralloides (Pallas, 1766). Marine Ecology, Pubbl. Staz. zool. Napoli I: 3 (4): 293-312.

D'Hondt, M.-J. \& A. Tixier-Durivault, 1975. Clavularia steveninoae n. sp., nouvel Octocoralliaire Stolonifera de Méditerranée. Cah. Biol. mar., 16: 585-592.

Косн, G. von, 1878. Bemerkungen über das Skelett der Korallen. Morph. Jahrb., 4: 316-322.

-_, 1891. Die Alcyonacea des Golfes von Neapel. Mitth. zool. Stn. Neapel, 9 (4): 652-676, pl. XXV.

Koren, J. D. O. Danielssen, 1883. Nye Alcyonider, Gorgonider og Pennatulider tilhørende Norges fauna. Bergens Mus. Skr., 2: i-xvi, 1-38, pls. I-XIII.
Kowalevsky, A. A.-F. Marion, 1883. Documents pour l'histoire embryogénique des Alcyonaires. Annls. Mus. Hist. nat. Marseille, (Zool.) 1 (4): 1-50, pls. I-V.

Madsen, F. J., 1944. Octocorallia. Danish Ingolf Exped., 5 (13): 1-65, pl. I.

Manuel, R. L., 1981. British Anthozoa. Synopses of the British Fauna (New Series), 18: 1-241 (Academic Press, London etc.).

Milne Edwards, [H.], 1848. Les Zoophytes. In: G. C. Cuvier et al. eds., Le règne animal distribué d'après son organisation: [i-v], 1-160, 1-94; Atlas: [i-v], 197, pls. 1-97 (Fortin, Masson et Cie., Paris).

SARs, M., 1861. Om nogle nye eller lidet bekjendte norske Coelenterater. Forh. Vidensk.-Selsk. Christiania, 1860: 140-151.

Thomson, J. A., 1927. Alcyonaires provenant des campagnes scientifiques du Prince Albert Ier de Monaco. Résult. Camp. scient. Prince Albert I, 73: [i-iii], 1-77, [1-10], pls. I-VI.

Tixier-Durivault, A. * M.-J. D'Hondt, 1975. Les Octocoralliaires de la Campagne Biaçores. Bull. Mus. natn. Hist. nat. Paris, (3) 1974 (252) (Zool., 174): 1361-1433.

Tixier-Durivault, A. F. Lafargue, 1969. Quelques Octocoralliaires des côtes françaises. Bull. Mus. natn. Hist. nat. Paris, (2) “1968” 40 (3): 621-629.

Weinberg, S., 1976. Revision of the common Octocorallia of the Mediterranean circalittoral. I. Gorgonacea. Beaufortia, 24 (313): 63-104.

- - 1977. Revision of the common Octocorallia of the Mediterranean circalittoral. II. Alcyonacea. Beaufortia, 25 (326): 131-166.

- - 1978. Revision of the common Octocorallia of the Mediterranean circalittoral. III. Stolonifera. Beaufortia, 27 (338): 139-176.

- , 1979. Autecology of shallow-water Octocorallia from Mediterranean rocky substrata, I. The Banyuls area. Bijdr. Dierk., 49 (1): 1-15. 